\title{
PERAN KELUARGA DALAM PENCEGAHAN HIV/ AIDS DI KECAMATAN PURWOKERTO SELATAN
}

\author{
Colti Sistiarani ${ }^{{ }^{*}}$, Bambang Hariyadi ${ }^{11}$, Munasib ${ }^{2)}$, Septi Maria Sari ${ }^{3)}$ \\ 1) Program Studi Kesehatan Masyarakat, Fakultas IImu-IImu Kesehatan, Universitas Jenderal Soedirman, Jl dr \\ Suparno Karangwangkal Purwokerto 53123, Indonesia \\ $\left.{ }_{2}^{2}\right)$ Program Studi IImu Gizi Fakultas IImu-IImu Kesehatan, Universitas Jenderal Soedirman, JI dr Suparno \\ Karangwangkal Purwokerto 53123, Indonesia \\ 3) Program Studi Sastra Inggris Fakultas IImu Budaya, Universitas Jenderal Soedirman, JI dr Suparno \\ Karangwangkal Purwokerto 53123, Indonesia
}

*)E-mail : coltisistiarani@yahoo.co.id

\begin{abstract}
Abstrak
Kecamatan Purwokerto Selatan masuk dalam zona merah penyebaran HIV/ AIDS di Kabupaten Banyumas. Oleh karenanya, tujuan penelitian ini adalah untuk mengetahui peran keluarga dalam pencegahan HIV/ AIDS. Selama ini salah satu kendala pencegahan penularan HIV dan AIDS justru berasal dari keluarga. Penelitian ini menggunakan pendekatan kualitatif melalui metode phenomenology, yaitu dengan melihat persepsi tindakan individu. Pengumpulan data dilakukan melalui wawancara mendalam kepada informan utama yaitu suami dan istri. Informan utama berjumlah enam pasangan suami istri sedangkan informan pendukung berjumlah 3 informan untuk triangulasi sumber. Analisis data menggunakan content analysis. Hasil penelitian menggambarkan bahwa informan telah mengetahui informasi tentang HIV/ AIDS, cara penularan, serta pencegahannya. Temuan di lapangan menunjukkan bahwa pencegahan HIV belum dilakukan secara maksimal baik oleh suami maupun istri. Hal ini disebabkan istri tidak memiliki kontrol terhadap suami tentang perilaku seksual. Sosialisasi tentang pencegahan HIV/ AIDS serta upaya pemberdayaan keluarga juga belum optimal dilaksanakan terkait pendidikan kesehatan dalam mencegah penularan HIV/ AIDS. Tindak lanjut penelitian ini yaitu pentingnya upaya penyebarluasan informasi tentang HIV/ AIDSkepada keluarga dan masyarakat.
\end{abstract}

Kata kunci : AIDS, HIV, keluarga, pencegahan, peran

\section{Family Role to Prevent HIV/AIDS at South Purwokerto Subdistrict}

\begin{abstract}
There are still many obstacles in prevention program of HIV and AIDS, especially for prevention program with family-based. Southern Purwokerto Subdistrict is in the red zone of HIV and AIDS spread in Banyumas District. The purpose of the study was to examine the role of families in preventing HIV and AIDS. This type of research was qualitative research through phenomenology method by seeing perception about individual action. Data collection was conducted through in-depth interviews to key informants that were husbands and wives informant. The main informants were 6 husbands and wives couples while the comparison informants were 3 informants for the source triangulation. Data analysis used content analysis. The results of this study illustrated that the couples already know about HIV/ AIDSinformation, how to spread HIV and AIDS, and how to prevent HIV and AIDS. The role of HIV prevention had not been done optimally either by husband and wife. Wife had no control over her husband about sexual behavior. Socialization on HIV/ AIDSprevention and family empowerment efforts was also not optimally implemented related to health education in preventing HIV/ AIDStransmission. The follow up of this research is the importance of efforts to disseminate information about HIV and AIDS to families and communities.
\end{abstract}

Key words : AIDS, HIV, family, perception, stigma

\section{PENDAHULUAN}

Acquired Immune Deficiency Syndrome (AIDS) merupakan penyakit yang disebabkan oleh virus Human Immunodefficiency Virus (HIV). Virus ini menyerang sel darah putih sehingga dapat merusak sistem kekebalan tubuh. Jika hal tersebut terjadi, maka tubuh menjadi rentan terhadap penyakit. Tubuh yang lemah dan tidak berdaya melawan penyakit menyebabkan berkembangnya kuman penyakit. HIV/ AIDS menular melalui kontak seksual yaitu terdapat pada cairan sperma dan cairan vagina, alat suntik yang terkontaminasi seperti penggunaan narkoba suntik, dan juga penularan melalui ibu ke janin (Shaluhiyah et al., 2013). Kondisi kasus HIV/ AIDS berdasarkan Sistem Informasi HIV/ AIDS dan IMS (SIHA) pada triwulan 2017 menunjukkan beberapa fakta yang membutuhkan perhatian lebih untuk dapat 
mencegah dan menanggulanginya.Jumlah infeksi HIV dilaporkan sebanyak 10.376 orang sedangkan jumlah penderita AIDS mencapai 673 orang pada triwulan 2017. Persentase kasus HIV tertinggi dilaporkan pada kelompok usia 25-49 tahun yaitu sebanyak 69,6 persen, sedangkan kasus AIDS tertinggi pada rentang usia 30-39 tahun yaitu sebesar 38,6 persen. Jumlah penderita AIDS pada ibu rumah tangga sebesar 12,3 persen. Provinsi Jawa Tengah merupakan provinsi yang berada di urutan ke-3 terbanyak kasus AIDS yaitu kasus HIV yang mencapai 6.531 kasus. Perincian kasus HIV di Jawa Tengah sebanyak 18.038 kasus, sedangkan kasus AIDS mencapai 6.531 kasus (Kemenkes, 2017).

Kasus HIV dan AIDS di Kabupaten Banyumas berdasarkan data Profil Kesehatan Dinas Kesehatan Kabupaten Banyumas tahun 2016 ditemukan pada rentang usia 15-34 tahun yang jumlahnya mencapai 325 kasus. Selanjutnya, pada rentang usia 35-44 tahun yaitu 234 kasus dan 45 tahun ke atas sebanyak 117 kasus. Kasus HIV/AIDS paling banyak ditemukan pada warga yang bekerja menjadi wiraswasta dengan kasus sebanyak 220 kasus, ibu rumah tangga 157 kasus, dan karyawan swasta 123 kasus. Kasus yang semakin meningkat di Kabupaten Banyumas menginiasi terbentuknya Perda tentang Penanggulangan HIV-AIDS. Perda No 14 Tahun 2015 tentang Penanggulangan HIV/AIDS juga telah dikembangkan di Kabupaten Banyumas. Hal tersebut menjadi acuan Dinas Kesehatan Kabupaten Banyumas untuk melakukan pencegahan HIV dan AIDS melalui kerja sama dengan tenaga kesehatan, bidan, PKK, kader kesehatan, camat, kepala desa, dan Puskesmas untuk selanjutnya membentuk forum Warga Peduli AIDS (WPA).

Perempuan lebih mudah terserang virus HIV yang berdampak epidemik dibandingkan laki-laki karena alasan biologis, sosiokultural, dan ekonomi. Pencegahan penyebaran infeksi HIV dapat dilakukan melalui program-program berbasis kesetaraan gender dan pemberdayaan perempuan (WHO \& ILO, 2005). Hasil penelitian Yulianti (2013) menyatakan bahwa perempuan tidak dapat menolak hubungan seksual dengan suaminya dan tidak dapat meminta suami untuk menggunakan kondom ketika melakukan hubungan tersebut yang kemudian memperbesar resiko terjangkit HIV/ AIDS ketika suami sudah terinfeksi. Faktor tabu dalam membicarakan seks, kesehatan reproduksi, dan informasi terkait seksualitas membuat wanita tidak ingin mendiskusikan masalah seks dengan suaminya.

Kajian sebelumnya di Kecamatan Purwokerto Selatan, menunjukkan bahwa 74 persen ibu atau istri merasa tidak mudah tertular HIV dan AIDS. Hal tersebut disebabkan istri merasa tidak mungkin tertular dari suami $(16,0 \%)$. Selain itu, hampir setengah perilaku istri $(44,0 \%)$ dalam pencegahan HIV dan AIDS terkategori kurang baik (Sistiarani et al., 2016). Hasil penelitian di Yogyakarta menyebutkan bahwa sikap ibu pada kelompok ibu yang memiliki suami yang tidak berisiko terkena HIV masih kurang peduli. Ibu menyatakan tidak mungkin tertular HIV dari suami sedangkan pada wilayah yang terkategori Desa Peduli AIDS, ibu lebih memahami definisi, penyebab, penularan, pengobatan dan perawatan serta tes HIV AIDS (Setiyawati, Shaluhiyah, \& Cahyo 2014). Hasil tersebut menunjukkan bahwa hubungan status perempuan dan sikap gender berperan dalam membentuk risiko terhadap HIV-AIDS. Hal ini disebabkan perbedaan peran laki-laki dan perempuan, keeratan hubungan, kemiskinan, dan kesetaraan gender. Istri hanya menuruti kehendak suami sehingga tidak dapat memutuskan sendiri segala sesuatu yang berkaitan dengan akses ke pelayanan kesehatan termasuk layanan konseling. Bukit dan Simanjutak (2015) menyatakan bahwa laki-laki memiliki peran besar dalam mengendalikan keadaan rumah tangga, baik dalam hal keuangan, pengambilan keputusan, dan pekerjaan.

Friedman (2010) menyebutkan bahwa keluarga memiliki fungsi yaitu fungsi afektif, fungssi sosialisasi, fungsi reproduksi, fungsi ekonomi dan fungsi perawatan kesehatan. Fungsi keluarga dapat terlaksana melalui upaya-upaya yang diwujudkan melalui peran suami dan istri secara bersama-sama dalam mencapai fungsi dalam keluarga. Fungsi perawatan kesehatan tercermin pada aspek penyediaan kebutuhan fisik makanan, pakaian tempat tinggal dan perawatan kesehatan. Pencegahan penularan HIV/ AIDS merupakan salah satu perwujudan upaya pencapaian fungsi perawatan kesehatan. Upaya pencegahan penularan HIV/ AIDS seyogyanya dilakukan melalui upaya peningkatan peran suami dan istri secara bersama-sama untuk memproteksi diri dari penularan HIV-AIDS.

Upaya preventif terkait pelayanan kesehatan HIV dan AIDS dapat dilakukan melalui peningkatan gaya hidup sehat, memahami bahaya, dan pencegahannya melalui tindakan asertif dari penyakit HIV-AIDS. Tindakan asertif 
adalah suatu kemampuan untuk mengomunikasikan hal yang diinginkan kepada orang lain, namun tetap menjaga dan menghargai orang tersebut. Sikap asertif menuntut seseorang untuk konsisten dan jujur dalam mengespresikan perasaan, pendapat, dan kebutuhan secara sadar tanpa memanipulasi. Pencegahan HIV dan AIDS dapat dilakukan melalui konsep pendekatan ABCD, yaitu $A$ (Abstinence) artinya absen seks atau tidak melakukan hubungan seks bagi orang yang belum menikah; B (Faithful) artinya bersikap setia kepada satu pasangan seksual (tidak berganti pasangan seks); C (Condom) artinya cegah penularan HIV melalui penggunaan kondom; dan D (Drug) artinya tidak menggunakan narkoba (Shaluhiyah et al., 2013). Ibu kurang dapat bersikap asertif dikarenakan takut dan merasa tergantung pada suami sehingga kurang terbuka dengan masalah seksual dan kurang percaya diri. Hal tersebut salah satunya disebabkan oleh adanya stigma yang dipersepsikan dalam membangun hubungan suami istri.

Stigma merupakan proses kehilangan kepercayaan diri seseorang di mata orang lain. Faktor penyebab munculnya stigma dan diskriminasi dalam konteks ini yaitu kurangnya pengetahuan mengenai HIV-AIDS, persepsi yang salah tentang cara penularan HIV-AIDS, laporan kasus epidemik dan anggapan penyakit HIV/ AIDS yang tidak dapat disembuhkan, serta prasangka dan ketakutan yang berlebihan terhadap masalah sosial yang sensitif (Sofro \& Sujatmoko, 2010). Stigma adalah cap buruk terhadap orang yang mengidap HIV dan AIDS. Stigma ada dua jenis, yaitu: felt stigma berupa persepsi norma masyarakat dan enacted stigma yaitu berupa tindakan diskriminasi yang jelas. Stigma dan diskriminasi merupakan kendala dalam upaya pendekatan program penanggulangan HIV dan AIDS. Adanya stigma dan diskriminasi membuat seseorang tidak mau melakukan tes HIV dan menyembunyikan status penyakitnya sehingga pengobatan dan akses layanan kesehatan kurang optimal. Hal membuka peluang penyebaran penyakit yang sulit dikendalikan (Shaluhiyah et al., 2013).

Stigma juga berasal dari dalam diri sendiri dan dari luar. Stigma dari dalam yaitu rasa takut pada diri ODHA (Orang dengan HIV/ AIDS) yang menginternalisasikan stigma dari luar. Stigma dari luar pada ODHA penguna narkoba suntik (penasun) diterima dalam bentuk diskriminasi, intimidasi, serta pembiaran. ODHA penasun yang terstigma kemungkinan membatasi diri untuk mencari bantuan, menunda pengobatan atau bahkan mengakhiri pengobatan penyakit HIV maupun untuk mengatasi adiksi akibat narkoba suntik (Ardani \& Handayani, 2017). Menurut Mahajan et al. (2008), stigma yang dirasakan berkaitan dengan empat komponen yang mencakup: 1) individu membedakan dan memberi label perbedaan pada manusia, 2) kepercayaan budaya yang dominan yang menghubungkan orang berlabel dengan karakteristik yang tidak diinginkan (atau stereotip negatif), 3) orang berlabel ditempatkan dalam kategori yang berbeda untuk mencapai beberapa derajat pemisahan "kita" dari "mereka", dan 4) orang berlabel mengalami status kehilangan dan diskriminasi yang menghasilkan hasil yang tidak setara. Pemberian stigma tergantung pada ketidaksetaraan dalam kekuatan sosial, ekonomi, dan politik yang memungkinkan keempat komponen stigma tersebut terungkap.

Indikator untuk mengukur stigma antara lain menilai berdasarkan aspek sosio-kognitif stigma. Stigma dapat diamati dari perspektif 'stigmatizers', yang mencakup masyarakat umum atau kelompok tertentu seperti petugas layanan kesehatan dan perspektif 'stigmatisasi' yang mencakup ODHA atau kelompok berisiko tinggi seperti pekerja seks komersial. Indikator untuk menilai sikap stigmati dilakukan dengan mengukur jarak dan dukungan sosial untuk tindakan yang dilakukan. Indikator-indikator ini menilai kesediaan seseorang untuk berinteraksi dengan ODHA dalam berbagai situasi, melalui serangkaian pertanyaan hipotetis tentang interaksi di rumah, lingkungan, dan tempat kerja. Indikator tersebut juga menanyakan tentang dukungan seseorang untuk mengarantinakan ODHA atau menolak masuknya ODHA ke wilayah tertentu. Kumpulan indikator lainnya memunculkan data tentang reaksi emosional terhadap ODHA. Indikator ini dirancang untuk mengukur sejauh mana seorang individu menyalahkan ODHA atas penyakit yang dialami, menganggap HIV sebagai pembalasan dari Tuhan, dan menimbulkan kemarahan, ketakutan, atau jijik terhadap ODHA. Dalam menilai stigma yang dirasakan atau dialami di antara ODHA, indikator mencakup cara ODHA merasa dan merespon pasangan, teman, keluarga dan masyarakat dalam memperlakukan ODHA secara umum (Mahajan et al., 2008).

Hasil penelitian Retnowati (2017) menyatakan bahwa tingkat pengetahuan tokoh agama tentang HIV/AIDS di Kabupaten Banyumas terkategori kurang yaitu sebesar $(59,1 \%)$ sedangkan pengetahuan yang baik sebanyak 40,9 persen. Selain itu, lebih dari satu perdua partisipan penelitian $(55,5 \%)$ melakukan stigma 
terhadap ODHA sedangkan yang tidak melakukan stigma sebanyak 45,5 persen. Hasil penelitian tersebut juga menunjukkan bahwa terdapat hubungan antara pengetahuan dengan stigma tokoh agama terhadap ODHA. Berdasarkan pemaparan berbagai fakta empiris di atas maka penelitian ini mempunyai tujuan untuk mengidentifikasi gambaran tentang peran keluarga dalam pencegahan HIV/ AIDSsehingga diperoleh pemahaman tentang penyakit dan stigma HIV AIDS, persepsi stigma, serta upaya yang dilakukan individu dan keluarga dalam upaya pencegahan HIV dan AIDS.

\section{METODE}

Penelitian ini adalah penelitian kualitatif dengan metode phenomenology yaitu studi memahami pengalaman tentang fenomena dan situasi. Phenomenology merupakan bagian pemahaman informan terhadap fenomena yang muncul dalam kesadaran dan pengalaman informan. Tujuan dari metode phenomenology adalah untuk memberikan gambaran yang akurat dari fenomena yang dipelajari. Phenomenology bukan hanya metode penelitian tetapi juga filosofi dan pendekatan. Peneliti berusaha memahami arti yang lebih dalam dan lebih lengkap dari sekadar pengalaman tertentu (Martha \& Kresno, 2016). Penelitian ini dilakukan di wilayah Kelurahan Teluk Kecamatan Purwokerto Selatan Kabupaten Banyumas. Kecamatan Purwokerto Selatan merupakan zona merah di Kabupaten Banyumas, Provinsi Jawa Tengah untuk penyebaran HIV/AIDS.

Penelitian ini menggunakan proses menggali informasi melalui wawancara mendalam semi terstruktur melalui personal kontak dengan cara mencari informan secara langsung di masyarakat. Informan utama sebanyak enam pasang suami dan istri. Wawancara mendalam dilakukan untuk menggali informasi; memahami pandangan, pengetahuan tentang penyakit HIV-AIDS; persepsi stigma; serta upaya/peran keluarga dalam pencegahan HIV-AIDS. Teknik pemilihan informan menggunakan teknik purposive sampling. Kriteria pemilihan informan yaitu informan yang berdomisili tetap di Kecamatan Purwokerto Selatan dan bersedia menjadi informan. Kriteria eksklusif yaitu informan yang tidak memiliki pasangan karena telah bercerai/ditinggal pasangan. Pendekatan untuk mengukur validitas data kualitatif dilakukan melalui triangulasi data yaitu melakukan wawancara dengan informan berbeda yaitu melakukan wawancara terhadap tiga informan pendukung yaitu tokoh agama dan tokoh masyarakat. Batasan konsep dalam penelitian ini mengidentifikasi pemahaman informan tentang penyakit HIV dan AIDS, penyebab HIV/AIDS, penularan HIV/AIDS. Penelitian ini juga mengidentifikasi pemahaman stigma HIV dan AIDS dan tindakan yang dilakukan jika berhadapan dengan penderita HIV/ AIDS serta upaya yang dilakukan untuk mencegah HIV dan AIDS.

Langkah pengumpulan data meliputi tahap pralapangan, menentukan daerah/lokasi penelitian, mengurus perizinan, menjajaki dan menilai keadaan lapangan, memilih dan memanfaatkan informan, pertimbangan etika penelitian. Etika penelitian dilakukan dengan cara memberitahukan secara terbuka maksud dan tujuan penelitian, menghargai informan, serta menuliskan segala yang diinformasikan informan sesuai dengan keadaan aslinya. Pengolahan dan analisis data dikumpulkan dan dituliskan dalam bentuk laporan lapangan. Setelah pengolahan data, proses selanjutnya yaitu interpretasi atau penafsiran data (Martha \& Kresno, 2016). Data penelitian dianalisis menggunakan proses induktif, artinya data dikumpulkan terlebih dahulu dan kemudian disimpulkan secara umum. Analisis data yang digunakan menggunakan metode content analysis, yaitu analisis berdasarkan topik dan masing-masing wawancara terdiri dari beberapa topik dalam kategori.

\section{HASIL}

\section{Karakteristik informan utama dan pendukung}

Dilihat dari usia, informan istri yang paling tua berumur 49 tahun dan usia termuda 34 tahun. Tingkat pendidikan terendah yaitu tamat SD dan pendidikan tertinggi yaitu SMP. Informan suami paling tua berusia 53 tahun dan usia termuda 38 tahun. Berdasarkan tingkat pendidikan, informan suami memiliki tingkat pendidikan tertinggi tamat SMA dan paling rendah tamat SMP. Informan pendukung terdiri atas tokoh agama (satu informan), serta tokoh masyarakat yaitu Ketua RT (dua informan). Informan tokoh masyarakat memiliki pekerjaan sebagai Pegawai Negeri Sipil dengan usia 45 tahun dan 60 tahun. Sementara itu, informan tokoh agama berusia 55 tahun.

Berdasarkan wawancara mendalam tentang HIV/ AIDS dan stigma, informan menyatakan telah memahami informasi tentang HIV dan AIDS. Informan mengerti bahwa HIV/ AIDS disebabkan oleh virus yang dapat menularkan, berbahaya, dan mematikan. 
Tabel 1 Pandangan Informan tentang HIV dan AIDS

\begin{tabular}{|c|c|}
\hline Pertanyaan & Pandangan Informan \\
\hline \multirow{3}{*}{ Penyakit HIV dan AIDS } & 1. Penyakit berbahaya karena belum ada obatnya \\
\hline & 2. Penyakit menular akibat virus \\
\hline & 3. Penyakit karena hubungan bebas/ hubungan seks \\
\hline \multirow[t]{5}{*}{ Cara penularan HIV-AIDS } & 1. Lewat jarum suntik \\
\hline & 2. Hubungan seksual/free sex \\
\hline & 3. Tranfusi darah \\
\hline & 4. Ibu ke janin \\
\hline & 5. Konsumsi narkoba \\
\hline Jika berhadapan dengan & 1. Dijauhi soalnya takut tertular \\
\hline \multirow{5}{*}{ ODHA } & 2. Diberi dukungan \\
\hline & 3. Diperlakukan sewajarnya \\
\hline & 4. Jangan dijauhi \\
\hline & 5. Waspada \\
\hline & 6. Dibantu \\
\hline \multirow[t]{6}{*}{ Cara mencegah HIV-AIDS } & 1. Tidak selingkuh/ hindari free sex \\
\hline & 2. Periksa ke pelayanan kesehatan \\
\hline & 3. Saling berkomunikasi dengan suami \\
\hline & 4. Pakai kondom \\
\hline & 5. Setia sampai akhir dengan pasangan \\
\hline & 6. Keluarga saling mendukung \\
\hline \multirow[t]{4}{*}{ Sumber informasi HIV-AIDS } & 1. TV \\
\hline & 2. Papan informasi \\
\hline & 3. Pelayanan Kesehatan \\
\hline & 4. Leaflet \\
\hline
\end{tabular}

Beberapa kutipan dari informan adalah sebagai berikut:

$$
\begin{aligned}
& \text { "HIV ya penyakit kelamin apa } \\
& \text { ya...ya menular" (Y, } 34 \text { tahun) } \\
& \text { "HIV dan AIDS itu suatu penyakit } \\
& \text { "menular.." ( } \mathrm{N}, 35 \text { tahun) } \\
& \text { "Penyakit akibat virus atau bakteri } \\
& \text { lupa saya mbaa...yang menyerang } \\
& \text { kekebalan tubuh" (F, } 40 \text { tahun) }
\end{aligned}
$$

Selanjutnya, seperti yang tersaji di Tabel 1, dapat diketahui bahwa HIV/AIDSmerupakan penyakit menakutkan yang menular melalui hubungan seksual/kelamin. Menurut informan penyakit ini dapat tertular oleh orang yang memiliki tabiat yang buruk/tidak benar. Informan menyatakan jika berhadapan dengan ODHA lebih membatasi diri dikarenakan khawatir apabila tertular. Dalam penelitian ini informan juga menyatakan akan memperlakukan sewajarnya serta tidak mengucilkan dan memberi semangat kepada ODHA untuk dibantu.

Seluruh informan menyatakan telah mengetahui informasi tentang HIV/AIDS, terutama definisi dan cara penularan, serta stigma yang melekat di masyarakat seputar info HIV-AIDS. Informan memersepsikan HIV sebagai penyakit yang disebabkan azab karena pergaulan tidak benar. Berikut ini pernyataan informan melalui kutipan hasil wawancara:

\author{
"Belum terlalu paham, Mbak. Nek \\ Bapak tah mungkin tahu lebih \\ banyak..." (K, 42 tahun) \\ "Nggak tahu loh, Mbak, cuma \\ pernah dengar sendiri-sendiri \\ saja..... nggak pernah diomongin \\ dengan suami" (N, 34 tahun) \\ "Ya, belum tahu, Mbak, kesehatan \\ reproduksi gitu ya,.." (T, 46 tahun) \\ "Suka hubungan sembarangan, \\ pergaulannya bebas...dijauhi ya \\ takut tertularlah" (S, 37 tahun)
}

Seluruh informan menyatakan tidak pernah mengakses pelayanan kesehatan untuk memeriksakan status HIV. Informan juga tidak pernah mendapatkan informasi terkait layanan pemeriksaan status HIV melalui klinik yang memberikan pelayanan pemeriksaan status HIV. Berikut kutipan pernyataan informan terkait hal tersebut:

"Saya tidak pernah periksa HIV, Mbak" (SR, 54 tahun)

"Kalau periksa, ya, ke Puskesmas Mbak, kalo pemeriksaan HIV sih belum pernah" (R, 31 tahun) "Informasi jarang ada sih, Mbak... kalau saya belum pernah. Cuma dengar-dengar saja mba." (K, 42 tahun) 
"Informasi ya paling dari $H P$, sosialisasi saya jarang ikut" (N, 31 tahun)

"Informasi dari bidan kalau pas Posyandu juga" (T, 46 tahun) "Informasi dari TV, kadang ada film menceritakan tentang HIV" (S, 36 tahun)

Seluruh informan menyatakan bahwa tidak pernah berdiskusi dengan suami tentang topik kesehatan reproduksi khususnya tentang perilaku seksualitas. Informan menganggap tabu membicarakan hal tersebut dengan suami/pasangan. Pendapat informan mengenai penggunaan kondom untuk mencegah HIV dan AIDS menyatakan bahwa

"Nggak pernah sih, Mbak,
membicarakan dengan suami
tentang kesehatan reproduksi
termasuk aktivitas seksual" (N, 34
tahun)
"Saya tidak pernah pakai kondom
ketika melakukan hubungan
seksual" (T, 34 tahun)
"Perilaku seksual suami kalau di
luar saya tidak pernah tahu, Mbak"
(S, 38 tahun)

Perilaku seksual yang berisiko pernah dilakukan oleh salah satu informan yaitu suami. Informan suami menyatakan pernah melakukan hubungan seksual dengan orang lain selain dengan istri. Berikut pernyataan informan:

"Ya, manusialah, saya tidak sesuci itu.. pernah terjadi seperti itu.. nek wong putih kaya ngapa rasane, wong ireng kaya ngapa rasane... (N, 38 tahun)

"Kalau saya pernah juga terpengaruh karena mengikuti arus, senang senang, ikut-ikut teman (sambil tertawa)" ( $T, 51$ tahun)

"Ya, saya pernah dulu waktu baru punya istri yang kedua...dulu kan masih muda.. kadang llihat orang kok cantik gituu, ya gitulah, Mbak, laki-laki sih...." (S, 52 tahun)

Seluruh informan istri menyatakan tidak dapat melakukan kontrol atas perilaku seksual suaminya, hanya pasrah dan menurut pada suami. Informan tidak menggunakan kesempatan untuk tawar-menawar kepada suami. Hal ini disebabkan budaya patriarki yang masih kental pada masyarakat desa. Berikut kutipan hasil wawancara dengan informan :

\begin{abstract}
"Pokoknya istri ya nurut sama suami, harus setia pokoknya, nggak pernah tahu suami ngapain, saya percaya saja sama suami" (S, 34 tahun)

"Budaya patriarki di sini masih ada, Mbak, tapi sekarang ya lumayan ibu-ibu sudah mulai aktif di masyarakat" (F, 40tahun) "Istri harus sopan dan tidak seenaknya, harapannya kalau istri sopan nanti suaminya jadi sayang" (Y, 38 tahun)
\end{abstract}

Berdasarkan hasil wawancara dengan informan pendukung menyatakan bahwa informasi kesehatan tentang HIV/ AIDS melalui program pemberdayaan masyarakat masih kurang dalam pelaksaannya. Menurut informan pendukung, perlu adanya penyuluhan kesehatan dari desa, kecamatan, dan Puskesmas Cilongok sehingga upaya pencegahan HIV/ AIDS melalui pemberdayaan masyarakat akan menjadi lebih baik. Berikut kutipan pernyataan informan pendukung yang dilakukan melalui wawancara mendalam:

"Belum pernah ada kegiatan
seperti itu, Mbak" (G/Tokoh
Agama, 55 tahun)
"Untuk pemberdayaan belum ada,
Mbak, mungkin kalau ada
penyuluhan dari pihak terkait
seperti Desa, Kecamatan,
Puskesmas, ya malah lebih baik"
(W/Ketua RT, 60 tahun)
"Memerangi HIV/ AIDS ya dari
keluarga dulu, mungkin informasi
dari PKK tentang apa itu
HIV-AIDS" (S/Tokoh Masyarakat
45 tahun)

Berdasarkan pendapat informan terkait peran masyarakat dalam mengurangi stigma terhadap penyakit HIV/ AIDS dikatakan bahwa dari RT pernah ada sosialisasi dan pengarahan untuk tidak mengucilkan warga yang terkena HIV-AIDS. Akan tetapi sosialisasi yang lebih banyak dilakukan berupa arahan/ imbauan supaya warga terhindar dari penyakit HIV-AIDS. Berikut pernyataan informan :

"Paling pengarahan, warga dikasih tahu kalau ada warga yang terkena ya jangan dijauhkan, jangan dikucilkan" (P/Ketua RT, 60 tahun)

"Pencegahan melalui upaya pemberdayaan lebih utama untuk 


\author{
dilakukan" (B/tokoh agama, 55 \\ tahun) \\ "Jarang ada pertemuan, paling ya \\ pengarahan PKK yang dilakukan \\ melalui perkumpulan sehingga \\ bisa dibicarakan. Kalau ada yang \\ sakit, ya dibantu" (T/Tokoh \\ masyarakat, 45 tahun)
}

\section{PEMBAHASAN}

Hasil penelitian menunjukkan bahwa ibu atau istri belum memahami tentang HIV dan AIDS karena masih kurangnya sosialisasi dan kegiatan pendidikan kesehatan reproduksi, khususnya tentang penyakit HIV dan AIDS. Sosialisasi kesehatan yang sudah pernah dilakukan seperti sosialisasi demam berdarah. Beberapa informan masih salah dalam memahami istilah HIV dan IVA adalah dua hal yang berbeda sehingga sosialisasi informasi kesehatan yang telah diperoleh tidak lengkap.

Selain itu, hasil penelitian juga menemukan bahwa nformasi mengenai HIV dan AIDS yang didapat suami dan istri berbeda karena kurangnya komunikasi keluarga dalam bertukar informasi. Komunikasi keluarga merupakan hal yang penting sebagai penentu ketahanan keluarga untuk mencegah tertularnya HIV-AIDS. Informan menyatakan bahwa pencegahan HIV dan AIDS dapat dilakukan dengan memeriksakan diri ke dokter atau pelayanan kesehatan seperti Puskesmas namun kenyataannya para informan juga belum pernah memeriksakan status HIV ke pelayanan kesehatan. Menurut Najib (2015), berbagai solusi permasalahan HIV dan AIDS yang dapat dilakukan diantaranya melaksanakan bimbingan sosial, pemberian konseling, dan pelayanan sosial termasuk pelayanan kesehatan sebagai langkah untuk mengantisipasi agar kematian akibat HIV dapat dihindari serta upaya untuk meningkatkan harapan hidup.

Ketidakpahaman masyarakat mengenai HIV/ AIDS merupakan salah satu faktor penyebab munculnya stigma dan diskriminasi. Stigma dan diskriminasi akan mendorong munculnya pelanggaran hak asasi pada ODHA dan keluarganya. Stigma dan diskriminasi dapat menyebabkan keparahan akan epidemik HIV-AIDS. Hal tersebut akan menghambat upaya pencegahan dan pemenuhan akses pelayanan dan pengobatan HIV/ AIDS yang masih kurang (Shaluhiyah, Musthofa, \& Widjanarko 2015).
Seluruh informan baik yang memiliki tingkat pendidikan dasar maupun menengah belum mengetahui informasi tentang stigma dan pencegahan HIV dan AIDS serta belum pernah melakukan pemeriksaan HIV dan AIDS. Hasil penelitian Dunlap (2016) menunjukkan bahwa responden memiliki pengetahuan tentang HIV yang meliputi cara penularan dan mengetahui bahwa infeksi HIV dapat menyebabkan AIDS, namun pengetahuan mereka tentang waktu paparan dan infeksi sebagian besar tidak tepat. Responden pada penelitian Dunlap (2016) menyatakan bahwa HIV dipercaya merupakan virus yang mematikan walaupun dilakukan pengobatan. Sebagian besar responden tersebut melaporkan bahwa telah menjalani tes HIV beberapa kali dan mendapat pembelajaran tentang HIV di sekolah, sedangkan responden yang lebih tua (pertengahan 40an sampai 60) melaporkan pengetahuan mereka berasal dari televisi atau jalanan.

Hasil penelitian lain menyatakan bahwa tingkat pengetahuan ibu tergolong rendah serta ada hubungan antara pengetahuan HIV dengan perilaku pencegahan HIV dan AIDS. Pemahaman yang kurang tepat tentang informasi HIV dan AIDS dapat dipengaruhi oleh tingkat pendidikan seseorang (Octavianty et al., 2015). Kurangnya pengetahuan masyarakat terhadap masalah HIV dan AIDS dari sudut pandang agama, mitos yang ada dalam masyarakat dapat memengaruhi tindakan stigma dan diskriminasi HIV dan AIDS (Ahwan, 2014).

Pengetahuan tidak berhubungan dengan kejadian Infeksi Menular Seksual (IMS) sedangkan perilaku berkaitan kejadian IMS. Perilaku seksual berkaitan dengan penggunaan kondom, jumlah pasangan seksual, serta pencegahan komprehensif HIV dan AIDS. Responden dengan tingkat pengetahuan yang lebih tinggi, kematangan usia ketika mulai aktif seksual, tidak melakukan perilaku seksual berisiko akan lebih dapat menurunkan kejadian IMS (Gani \& Utomo, 2016). Suami dan istri memiliki peran yang berbeda dalam pencegahan HIV-AIDS. Istri cenderung mengikuti keinginan suami dan tidak memiliki kemampuan dalam upaya pencegahan HIV/ AIDS dalam keluarga. Perilaku pencegahan Infeksi Menular Seksual (IMS) termasuk HIV dan AIDS dengan menggunakan kondom masih belum dilakukan. $\mathrm{Hal}$ tersebut dikarenakan merasa tidak melakukan perilaku seksual berisiko dengan orang lain (Abhinaja \& Astuti, 2013). 
Informan suami menyatakan bahwa seseorang akan melakukan hubungan seksual dengan pasangan lain selain istri di rumah karena berbagai faktor seperti keadaan dalam keluarga, hubungan suami istri yang kurang harmonis, istri tidak dapat memuaskan kehendak suami, suami merasa jenuh, dan juga pengaruh lingkungan sosial atau teman dalam bergaul. Lingkungan pergaulan kurang baik mengakibatkan seseorang cenderung terpengaruh dan ikut melakukan perbuatan berisiko. Hal ini sesuai dengan penelitian Setyadani (2013) yang menemukan bahwa alasan seseorang melakukan seks bebas adalah karena nafsu yang timbul, rasa suka sama suka, dan ikut-ikutan teman.

Hasil penelitian Gyawali et al. (2014) menunjukkan bahwa perempuan usia reproduktif yang menikah telah mengetahui tentang HIV sebesar (70,2\%). Perempuan menyatakan bahwa seks yang tidak aman, transfusi darah yang terinfeksi, berbagi jarum suntik, dan transmisi ibu ke anak merupakan cara penularan HIV. Upaya pencegahan HIV dan AIDS dapat dilakukan melalui penggunaan kondom jika melakukan seks di luar nikah, penggunaan jarum suntik steril, membatasi seks dengan pasangan dan keamanan darah. Seks di luar nikah, berbagi jarum suntik dan pisau cukur dianggap perilaku berisiko. Di luar itu, sekitar $(4,9 \%)$ perempuan memiliki pengalaman seksual di luar nikah. Perempuan yang melakukan seks di luar nikah menggunakan kondom secara teratur sebanyak $(26,6 \%)$. Perempuan usia reproduktif yang menikah memiliki kesadaran terbatas mengenai penularan HIV dan tindakan pencegahan. Praktik pencegahan HIV masih kurang sehingga menunjukkan adanya kesenjangan pengetahuan dan perilaku.

Hasil penelitian ini juga menemukan bahwa istri setiap hari menghabiskan waktunya di rumah mengurus keluarga yang cenderung tidak melakukan perilaku berisiko seksual. Hal ini sesuai penelitian Sari dan Suwartiningsih (2013) yang menyatakan bahwa ibu atau istri memiliki perilaku seksual tidak berisiko sehingga kemungkinan apabila tertular infeksi HIV dan AIDS berasal dari suami. Perilaku seksual suami tidak diketahui oleh istri dikarenakan pasangan suami istri tidak pernah terbuka dengan permasalahan seksual yang baik atau berisiko sehingga lebih rentan tertular HIV-AIDS. Hal ini sejalan dengan penelitian Saspriyana, Suwiyoga, dan Darmayasa (2015) yang menyatakan bahwa status HIV suami dapat meningkatkan risiko terjadinya ibu hamil terinfeksi HIV sebesar 12 kali.
Perilaku seksual dapat menyebabkan penularan HIV/ AIDS di dalam keluarga terutama pada pasangan dan anak. Kurangnya informasi istri tentang perilaku seksual yang dilakukan oleh suami akan menyebabkan istri tidak dapat mengontrol dan menekan perilaku seksual suami. Hal ini juga menyebabkan perempuan lebih rentan terhadap penularan HIV-AIDS. Kerentanan perempuan terhadap HIV/ AIDS lebih banyak disebabkan oleh ketimpangan gender seperti perempuan tidak bisa mengontrol perilaku pasangan, serta kurangnya akses untuk mendapatkan informasi dan pelayanan HIV-AIDS. (Lestari, Hargono, \& Subarniati, 2013).

Budaya patriarki dapat dikaitkan dengan berbagai permasalahan sosial dan realitas di Indonesia. Menurut Sakirna dan Siti (2017), munculnya masalah sosial karena ada tekanan terhadap kebebasan dan pelanggaran hak perempuan. Perempuan cenderung mengalami ketidakadilan gender akibat subordinasi yaitu posisi perempuan yang cenderung di bawah laki-laki/suami. Pengsubordinasian dianggap sebagai sesuatu yang digambarkan struktural budaya patriarki. Budaya patriarki yang dibentuk dalam masyarakat menempatkan perempuan sebagai penerima nafkah dan hanya berperan di sektor domestik. Menurut Dalimoenthe (2011), faktor sosiokultural memengaruhi perempuan tidak dapat menolak hubungan sosial dengan pasangannya. Faktor tabu membicarakan seks, kesehatan reproduksi, dan informasi lainnya membuat perempuan sulit membicarakan masalah seks dengan pasangannya. Penelitian Esariti (2016) menyatakan tentang pentingnya kontribusi rumah tangga miskin untuk mengakses informasi dan manfaat program terkait dengan pola relasi gender dan konstruksi sosial masyarakat.

Hasil penelitian Sistiarani, Elviera dan Anandari (2016) menyatakan bahwa hampir dua pertiga istri $(62,0 \%)$ memiliki keyakinan positif terkait upaya pencegahan HIV dan AIDS. Ditemukan juga bahwa hampir sepertiga istri $(22,0 \%)$ setuju penularan HIV tidak dapat dicegah dengan cara apa pun dan istri tidak punya kewenangan untuk menawarkan kondom kepada suami $(33,0 \%)$. Perbedaan status dan peran dalam keluarga membuat akses informasi dan pencegahan terhadap infeksi menular seksual pada perempuan menjadi terbatas. Peran perempuan yang tidak dapat mengambil keputusan sendiri berdampak pada akses layanan kesehatan yang ada. Hal ini sesuai dengan penelitian Maimunah (2012) yang menyatakan bahwa masih rendahnya 
informasi HIV dan AIDS serta belum diterimanya program kondom bagi perempuan. Kondom merupakan intervensi yang hemat dan sederhana dalam mencegah infeksi HIV. Penggunaan kondom yang rendah pada laki-laki didasari faktor malu untuk membeli kondom dan berkurangnya kenikmatan seksual. Pada perempuan penggunaan kondom yang masih rendah disebabkan kondom mengganggu kenikmatan seksual dan ketidakmampuan meyakinkan pasangan untuk menggunakan kondom (Katikiro \& Njau, 2012).

Studi Alo (2013) mengungkapkan bahwa wanita dibatasi oleh lingkungan sosial dalam negosisasi seks yang aman. Faktor-faktor yang membatasi perempuan antara lain ketakutan akan perpisahan dengan suami, ketergantungan ekonomi, kekerasan dalam rumah tangga, dan kesulitan untuk mengungkapkan kepada suami agar mau menggunakan kondom. Peningkatan akses terhadap pendapatan dan pendidikan adalah penting namun tidak secara langsung dapat memberdayakan perempuan untuk mencegah infeksi HIV. Keterbatasan perspektif perilaku dan determinan sosial menunjukkan perlunya model pencegahan kombinasi, yang berfokus pada faktor sosial, perilaku dan biomedis saling tumpang tindih dalam membentuk hasil kesehatan.

Keputusan keluarga berpengaruh pada pemilihan pelayanan kesehatan yang akan diakses dalam pencegahan HIV-AIDS. Informan menyatakan tidak pernah melakukan pemeriksaan HIV/ AIDS karena merasa takut dan menganggap pemeriksaan tersebut tidak diperlukan dan merasa tidak memiliki gejala HIV/AIDS. Penelitian Baroroh, Hidayati \& Kusumawardani (2014) menyebutkan bahwa pemeriksaan dilakukan sebagai upaya pencegahan HIV-AIDS. Apabila belum melakukannya, hal itu dikarenakan beberapa alasan seperti belum adanya keberanian melakukan tes HIV, adanya perasaan takut mengetahui hasil positif, serta tidak ingin mengetahui status HIV pada diri sendiri. Kinsler et al. (2007) menyatakan bahwa akses yang tidak baik dari pelayanan kesehatan sangat penting untuk meningkatkan status kesehatan, kesejahteraan, dan peningkatan kualitas hidup orang yang positif HIV-AIDS. Penelitian Piper et al. (2012) menyatakan bahwa sebagian besar perempuan belum pernah melakukan tes HIV. Hal ini dikarenakan perempuan memiliki keyakinan tidak berisiko terkena HIV, risiko tertular HIV yang dipercaya kemungkinan lebih besar terkena pada individu yang belum menikah. Kajian dari Kaur et al. (2013) menyatakan lebih dari separuh ibu di daerah perdesaan maupun di perkotaan tidak mengetahui tentang HIV dan AIDS secara utuh. Ibu di perdesaan dan di perkotaan yang tidak memiliki pengetahuan tentang penyebab HIV/AIDS sebesar (66,0\%), selebihnya kurang pengetahuan tentang tanda dan gejala AIDS. Lebih dari tiga perempat ibu baik di perdesaan $(88,0 \%)$ maupun di perkotaan $(85,6 \%)$ mengetahui bahwa AIDS harus dicegah. Persepsi risiko HIV mungkin rendah namun risiko tersebut berkaitan dengan perilaku suami.

Penelitian Yebei, Fortenberry, dan Ayuku (2008) menyebutkan bahwa perbedaan jenis kelamin dan wilayah perdesaan dan perkotaan dapat berkaitan dengan pengalaman merasakan stigma HIV. Hal tersebut disebabkan wilayah perdesaan dan perkotaan berbeda dalam jaringan sosial. Menurut Shaluhiyah Musthofa, dan Widjanarko (2015) stigma ODHA pada perempuan yang hidup dengan HIV dipengaruhi oleh sikap keluarga terhadap ODHA dan persepsi terhadap ODHA. Penelitian Ojikutu et al. (2016) menyebutkan bahwa perempuan dengan HIV merasakan stigma dari masyarakat yang mengaitkan infeksi HIV dengan pekerjaan seks dan banyak pasangan seksual. Intervensi diperlukan untuk mengurangi stigma dan mempromosikan kesetaraan gender. Penelitian Butt et al. (2010) menjelaskan bahwa sumber stigma dapat berupa budaya. Perempuan yang percaya kepada suaminya karena tidak melakukan penyimpangan norma karena takut merusak reputasi. Perempuan cenderung menarik diri dari keluarga karena berhubungan dengan sanksi budaya. Upaya perempuan agar tetap terjaga dan terlindungi dari penularan penyakit HIV/AIDS berkaitan dengan keluarga, masyarakat, dan budaya.

Menurut Maiorana et al. (2016), strategi mobilisasi sebagai kunci pencegahan HIV namun masih dianggap kurang pelaksanaannya. Pemberdayaan dapat membantu memperbaiki perilaku pencarian kesehatan dan mengonsolidasikan norma sosial yang mendukung perilaku pencegahan di kalangan gay dan transgender. Penelitian Masoudnia (2015) menyebutkan bahwa terdapat pengaruh antara kesadaran warga tentang HIV/AIDS, sikap, persepsi terhadap diskriminasi ODHA, serta faktor budaya yang cenderung menstigma dan mendiskriminasi pengidap HIV-AIDS. Malave et al. (2014) melaporkan bahwa laki-laki lebih banyak melakukan pemeriksaan HIV dibanding perempuan. Hal ini karena perempuan lebih 
berisiko memperoleh stigma. Pendekatan berbasis gender diperlukan untuk mencegah HIV dan pengurangan stigma. Penelitian lainnya yaitu Stangl et al. (2013) stigma dan diskriminasi harus menjadi fokus dari upaya pencegahan. Penelitian Neuman et al. (2013) menyebutkan bahwa ada pengaruh antara pengungkapan dan diskriminasi interpersonal dan pemanfaatan kelompok pendukung dengan diskriminasi perawatan kesehatan, rujukan, dan pengobatan. Temuan penelitian ini menegaskan perlunya upaya-upaya pencegahan HIV/ AIDS melalui pengembangan program berbasis keluarga mengingat hasil utama penelitian ini menemukan bahwa pengetahuan dan kesadaran tentang bahaya HIV/ AIDS masih rendah bukan hanya pada istri namun juga suami. Selain itu, pembicaraan mengenai seksualitas suami istri masih merupakan hal tabu dalam hubungan suami istri di dalam keluarga, padahal ada resiko bahwa suami lah yang menularkan kepada istri. Fakta tersebut menegaskan bahwa family-based program memang sangat dibutuhkan untuk mencegah penyebaran HIV/ AIDS di masyarakat.

\section{SIMPULAN DAN SARAN}

Hasil penelitian menemukan bahwa informan telah memahami tentang HIV dan AIDS. Informan ada yang belum memahami penyebab, cara penularan serta pencegahan HIV dan AIDS. Informan tidak mengetahui tentang istilah stigma HIV dan AIDS, namun informan menyatakan akan menjauhi/membatasi diri jika berhadapan dengan ODHA. Informan merasa kasihan dan merasa ingin membantu/ memberi dukungan namun tidak mengucilkan jika berhadapan dengan ODHA. Peran pencegahan HIV/ AIDS belum maksimal untuk dilakukan karena istri tidak memiliki kontrol terhadap perilaku seksual terhadap suami. Selain itu, mengenai penggunaan kondom untuk mencegah penularan HIV/ AIDS, hanya satu pasangan suami istri yang pernah menggunakannya. Sosialisasi dan pemberian informasi tentang pencegahan HIV/ AIDS belum banyak dilakukan dan bahkan jarang sehingga upaya pemberdayaan di masyarakat masih kurang.

Berdasarkan penelitian, kegiatan Tridharma perguruan tinggi diharapkan dapat membantu upaya pencegahan HIV/ AIDS. Dalam hal ini, perguruan tinggi dapat melakukan kerja sama lintas sektoral dengan pihak terkait (Dinas Kesehatan dan Komisi Penggulangan HIV/ AIDS di masing-masing wilayah) untuk memberikan informasi yang benar mengenai HIV/ AIDSdi lingkungan keluarga, khususnya pada pasangan suami dan istri. Hal ini penting sebagai upaya untuk mengurangi persepsi negatif atau stigma pada individu dan keluarga. Peran pencegahan HIVI AIDS dapat ditingkatkan melalui upaya peningkatan kewaspadaan individu dan keluarga untuk melakukan pencegahan $A B C D$ sehingga penularan HIV/ AIDS dapat dicegah. Sebagai rekomendasi, diperlukan strategi pendekatan sosialisasi dan pemberian informasi berbasis gender untuk mencapai kewaspadaan penularan HIV/ AIDS terkait upaya peningkatan pengetahuan dan penurunan stigma.

\section{DAFTAR PUSTAKA}

Abhinaja, I.G.W., Astuti, \& P.A.S. (2013). Pengetahuan, sikap ibu rumah tangga mengenai infeksi menular termasuk HIV/AIDS serta perilaku pencegahannya di Kelurahan Sanur, Kecamatan Denpasar Selatan. Community Health 1 (3) : 218-228

Ahwan, Z (2014). Stigma dan diskriminasi HIV \& AIDS pada orang dengan HIV dan AIDS [ODHA] di masyarakat basis anggota Nahdlatul Ulama' [NU] Bangil Jurnal Kebangsaan 6(1):1-15. universitas.yudharta.ac.id/wp-content/up loads/2014/11/11.pd

Alo, O.I (2013). Empowering Yoruba Women in Nigeria to Prevent HIV/AIDS: The Relative Significance of Behavioural and Social Determinant Models. Exchanges: the Warwick Research Journal, 1 (1): 59-81

Ardani, I., \& Handayani, S. (2017). Stigma terhadap Orang dengan HIV/AIDS (ODHA) sebagai Hambatan Pencarian Pengobatan: Studi Kasus pada Pecandu Narkoba Suntik di Jakarta. Buletin Penelitian Kesehatan. 45 (2): 81-88. DOI:10.224435/bpk.v45i2.6042.81-88

Baroroh, I., Hidayati, N., \& Kusumawardani, D. (2014). Pengetahuan dan sikap Wanita Rawan Sosial Ekonomi (WRSE) tentang pencegahan penanggulangan HIV/AIDS di Kota Pekalongan. Jurnal Litbang Kota Pekalongan. 7(1) : 22-39

Bukit, L.M., \& Simanjuntak, M. (2015). Dimensi budaya dan penyebaran penyakit HIV/AIDS di Perkumpulan Kasih Rakyat. Perspektif Sosiologi. 3 (1) : 90-103

Butt, L., Morin, J., Numbery, G., Peyon, I., Goo, A. (2010). Stigma dan HIV/AIDS di 
wilayah pegunungan Papua. Pusat Studi Kependudukan Universitas Cendrawasih Papua dengan University of Victoria Canada

Dalimoenthe, I. (2011). Perempuan dalam cengkeraman HIV/AIDS : kajian sosiologis feminis perempuan ibu rumah tangga. Jurnal Komunitas. 5(1):41-48

Dunlap, E. (2016). Knowledge, awareness and behavior : HIV and Disasters. Journal Alcohol Drug Depend. 4(1) : 230

Esariti, L. (2016). Determinan analisis gender pada pemberdayaan miskin perkotaan. Ruang. 2 (3) : 751-760

Friedman, M. 2010. Buku Ajar Keperawatan keluarga : Riset, Teori, dan Praktek. Edisi ke-5. Jakarta: EGC

Gani, Y., Utomo, S.W. (2016). The relation between knowledge of HIV-AIDS, attitude, behaviour and the incidence of STIs In Housewives In Bukittinggi City, West Sumatra province 2013. Asian Journal of Applied Sciences. 4 (3) :662-668

Gyawali, K., Paneru, D. K., Paudel, D. P., Joshi, K. R., \& Paudel, M. (2014). Human immunodeficiency virus related knowledge, risk perception and practices among married women of reproductive age: A Cross-sectional study from Mid-western Development Region, Nepal. Annals of Medical Health Sciences Research. Sep-Oct; 4(5): 786790.

Kaur, H., Singh, G. P. I., Soni, R. K. (2013). A community based study of HIV/AIDS knowledge among housewives of Rural And Urban Background In Punjab. International Journal of Research and Health Sciences. 2(1): 236-242

Katikiro, E. \& Njau, B. (2012). Determinant of behavioural change for condom use among out of school youths in Tanzania. Global Journal of Medicine and Public Health. GJMEDPH, 1 (5) September-October page 63-53. www.gjmedph.org.

Kementerian Kesehatan Republik Indonesia. (2017). Laporan Situasi Perkembangan HIV/ AIDS dan PIMS di Indonesia Januari-Maret 2017. Direktorat Jenderal Pencegahan dan Pengendalian Penyakit ; Jakarta

Kinsler, J.J., Wong, M.D., Sayles, J.N., Davis,C., Cunningham, W.E. (2007).
The effect of perceived stigma from a health care provider on access to care among a low income HIV positive population. AIDS Patient Care and STDs. 21(8) : 584-592

Lestari, D., Hargono, R., \& Subarniati, R. (2013). Pengembangan Program Pemberdayaan Peningkatan Kemandirian lbu Rumah Tangga Pengidap HIV. Buletin Penelitian Sistem Kesehatan. 16(3) : 283-295

Mahajan, A.P., Sayles, J.N., Patel, V.A., Remien, R.H., Ortiz, D., Szekeres, G., \& Coates, T.J., (2008). Stigma in the HIV/AIDS epidemic: A review of the literature and recommendations for the way forward AIDS. 2008 Aug; 22(Suppl 2): S67S79.DOI: 10.1097/01.aids.0000327438. 13291.62

Maimunah. (2012). Ketidakadilan gender terhadap perempuan local dalam upaya penanggulangan HIV/AIDS. Jurnal Masyarakat Kebudayaan dan Politik. 23 (1) : 174-183

Maiorana, A., Kegeles, S.m Salazar, X., Konda, K., Santiesteban, A.S., Caceres, C. (2016). 'Proyecto Orgullo' an HIV prevention, empowerment and community mobilisation intervention for gay men and transgender women in callao/lima, peru. Glob Public Health. 11(7-8): 1076-1092. DOI: $10.1080 / 17441692.2016 .1161814$

Malave, S., Ramakrisnhna, J., Heylen, E., Bharat, S., Ekstrand, M.L. (2014). Differences in testing, stigma, and perceived consequences of stigmatization among heteroseksual men and women living with HIV in Bengaluru, India. AIDS Care. 26 (3) : 396-403

Masoudnia, E. (2015). Public perception about HIV/AIDS and discriminatory syndrome in iran. Sahara Journa of Aspect of HIV/AIDS. 12 (1): 116-122

Martha, E., \& Kresno, S. (2016). Metodologi Penelitian Kualitatif untuk Bidang Kesehatan. Jakarta: PT RajaGrafindo Persada

Najib, A. (2015). Pola Kebijakan Penanggulangan dan penularan terhadap perkembangan virus HIV/AIDS dan peran pekerja sosial. Panggung Hukum. 1(2) : 189-216 
Neuman, M., Obermeyer, M.C., Cherutich, P., Desclaux, A.H., Ky-zerbo, O., Namakhoma, I., Wanyenze, R. (2013) Experiences of stigma, stigma, discrimination, care and support among people living with HIV : a four country study. AIDS Behaviour. 17 (5) : 1796-1808

Octavianty, L., Rahayu, A., Rahman, F.,\& Rosadi, D. (2015). Pengetahuan, sikap dan pencegahan HIV dan AIDS pada Ibu Rumah Tangga. Jurnal Kemas. 11 (1) : 53-58

Ojikutu, B.O., Pathak, S., Srithanaviboncai, K., Limbada, M., Friedman, R., Li, S., Mimiaga, M. J., Mayer, K.H., Safren, S.A. 2016. Community cultural norms, stigma and disclosure to sexual partners among women living with HIV in Thailand, brazil and Zambia (HPTN 063). Plos One . 6 (May) : 1-16

Piper, C; Elder, K; Olatosi, B; Onsomu, E; Williams, EM; Sebastian, N; Ogbuano, C; Lee, W; Glover, SH. (2012). Beliefs and perception of risk of HIV among women that have never been tested for HIV in the United States. Journal of The National Medical assosiation. 104, issue 9-10. September-October 2012. Page 441-448

Retnowati, M. (2017). Hubungan pengetahuan dengan stigma tokoh agama terhadap orang dengan HIV AIDS di Kabupaten Banyumas. Bidan Prada Jurnal Ilmiah Kebidanan. 8(1):86-94

Sakirna, A.I., \& Siti A, D.H. (2017). Menyiroti budaya patriarki di Indonesia. Social Work Journal 7 (1) : 1-129

Sari, B.W.N., \& Suwartiningsih, S. (2013). Pemberdayaan perempuan dalam penanggulangan HIV/AIDS di Kota Salatiga. Jurnal Studi IImu Pembangunan Interdisiplin. 22(2): 118-135

Saspriyana, K.Y., Suwiyoga, K., \& Darmayasa, L.M. (2015) Karakteristik umur, pendidikan dan pekerjaan istri serta status suami sebagai faktor risiko terjadinya infeksi HIV pada ibu hamil. Jurnal IImiah Kedokteran. 46 (1) : 3-8

Setiyawati, N.,Shaluhiyah, Z., \& Cahyo, K. (2014). Sikap ibu rumah tangga terhadap tes HIV AIDS di Sleman Yogyakarta. Jurnal Promosi Kesehatan Indonesia.9(1): 56-66
Setyadani, A.S. (2013). Perilaku kesehatan reproduksi pada anak jalanan dengan seks aktif di kota semarang. Jurnal Kesehatan Masyarakat. 9 (1) : 30-36

Sistiarani, C., Gamelia, E., \& Anandari, D. (2016). Analisis pencegahan HIV/ AIDS pada ibu rumah tangga di Kecamatan Purwokerto Selatan. Laporan Penelitian Fakultas IImu-IImu Kesehatan Universitas Jenderal Soedirman (sedang dalam tahap publikasi)

Shaluhiyah, Z., Hasyim, H., Amiruddin, R, Syarifah, Nopriadi, Subirman, Mardjan, Momongan, N., Prabawa, A., Virani, D., Susanti, Y., Fikri, I.M., Suryoputro,A., Prijono, Leonita, E., Indrasari, W., \& Siregar, K.N. (2013) Kurikulum dan Modul Penanggulangan HIV dan AIDS Program Studi IImu Kesehatan Masyarakat. Komisi Penanggulangan AIDS Nasional : Jakarta

Shaluhiyah, Z., Musthofa, S. B., Widjanarko, B. (2015). Stigma masyarakat terhadap orang dengan HIV/AIDS. Kesmas ; Jurnal Kesehatan Masyarakat Nasional. 9 (4) : 333-339

Sofro, M.A.U., \& Sujatmoko, S.A. (2010). Sehat dan Sukses dengan HIV-AIDS. Penerbit Gramedia Elex Media Komputindo : Jakarta

Stangl, A., Lioyd, J.K., Brady, L.M., Holland, C.E., Baral, S. (2013). A systematic review of interventions to reduce HIV related stigma and discrimination from 2002 to 2013 : how far we come?. Journal of the International AIDS Society. 16 (2) ; 18-34

World Health Organization (WHO), International Labor Organization (ILO). (2005). Pedoman bersama WHO/ILO tentang pelayanan kesehatan dan HIV dan AIDS. Direktorat Pengawasan Kesehatan Kerja Direktorat Jenderal Pembinaan Pengawasan Ketenagakerjaan. Jakarta

Yebei, V., Fortenberry, J.D., Ayuku, D.O. (2008). Felt stigma among people living with HIV/AIDS in rural and urban Kenya. African Health Science. 8 (2) : 97-102

Yulianti, A.P. (2013). Kerentanan perempuan terhadap penularan HIV \& AIDS: Studi pada Ibu rumah tangga pengidap HIV/AIDS di Kabupaten Pati, Jawa Tengah. PALASTREN, 6. (1), 185-200. 